\title{
The effect of short-term lithium treatment on head twitches induced by 5 -hydroxytryptophan in mice
}

\author{
Halina Szymczyk, Zofia Danilczuk, Marian Wielosz
}

Department of Experimental and Clinical Pharmacology, Medical University of Lublin, Jaczewskiego 8, 20-090 Lublin, Poland

\begin{tabular}{l}
\hline ARTICLE INFO \\
\hline Received 01 October 2015 \\
Accepted 28 October 2015
\end{tabular}

\section{Keywords:}

lithium,

serotonin,

head twitches,

mice.

\begin{abstract}
The effectiveness of lithium in the treatment of affective disorders is well documented. However, the mechanism of this effect is still unknown. The purpose of this study was to investigate the effect of lithium on serotonergic neurons. The evaluation of the serotoninergic system activity was performed on the basis of an experimental model of head twitch response triggered by direct or indirect stimulation of serotonin 5-HT2 receptors in the brain. The obtained results indicated that the lithium chloride co-applied with a direct precursor of serotonin - 5-hydroxytryptophan used in a threshold dose and with carbidopa, generated head twitch response in mice. What is more, an enhancement of head twitch response in mice was observed after repeated 5-hydroxytryptophan application in head twitch-evoking doses. Moreover, inhibition of the serotonine storage in nerve endings in mice was evoked by reserpine administration. Furthermore, lithium increased the effect of 5-hydroxytryptophan given in a threshold dose and a head twitchevoking dose, respectively. In addition, when P-chlorphenylalanine (pCPA), an inhibitor of the serotonin synthesis within the serotonergic neurons, was given simultaneously with the lithium chloride, carbidopa and 5-hydroxytryptophan in the threshold dose, as well as with the lithium chloride and 5-hydroxytryptophan given at head twitchevoking dosage, $\mathrm{pCPA}$ administration decreased the number of head twitches responses in both experimental models, as well as in the reserpinized mice subjected to the lithium chloride and 5-hydroxytryptophan application. Finally, 5,7-dihydroxytryptamineevoked serotoninergic nerve endings destruction led to absolute inhibition of headtwitch response when observed after the lithium and 5-hydroxytryptophan application. Moreover, the increase by lithium 5-hydroxytryptophan-evoke head twitch response was inhibited by administration of the ritanserine - a 5-HT2 serotonin receptor blocking agent.

In summary, our data show that lithium induced an enhancement of serotonergic neurotransmission due to its action on presynaptic serotonergic terminals.
\end{abstract}

\section{INTRODUCTION}

Lithium is a unique drug in its clinical profile usage within the field of psychiatry, as it holds both antidepressant and antimanic properties and also prophylactic actions in bipolar and unipolar affective disorder [12]. The mechanism involved in this clinical profile of lithium have been a subject of much behavioral and biochemical investigation. It has been proposed that the catecholaminergic, serotonergic and cholinergic neuron systems in the brain may be involved [10].

\footnotetext{
* Corresponding author

e-mail: halina.szymczyk@umlub.pl
}

Researchers have demonstrated that lithium potentiated the 5-hydroxytryptophan induction of head twitches in rats that was abolished by pretreatment with the serotonin synthesis inhibitor - p-chlorphenylalanine [15]. This effect is thought to be brought about by lithium bringing about an increase in the tryptophane uptake inside the brain and inducing an increase in serotonin synthesis within the brain's neurons $[2,8]$.

Many authors have noted that the behavioural syndrome in rats and mice deemed 'head twitching' is induced by the administration of serotonin precursors (5-hydroxytryptophan) or serotonin agonists (e.g. DOI), and have utilized this effect as a model for response as mediated by 5-HT2 
receptors $[6,14]$. Head twitching may be also induced by lithium alone in rats or by lithium in combination with reserpine in mice [18]. Both effects are strongly inhibited by the administration of antiserotonergic drugs (e.g. ritaserine) or by administration of a serotonin synthesis inhibitor (p-chlorphenylalanine) [13].

The present study was carried out to obtain further information about the lithium effect on the functional pool of serotonin in the serotonergic nerve terminals.

\section{MATERIALS AND METHODS}

Animals. Albino Swiss male mice weighting 20-28g were used in this experiment. The animals were housed under natural light/dark cycles, having free access to food and water, and were rando mly assigned to experimental groups consisting of 8 mice. All behavioural observations were performed between $11 \mathrm{a} . \mathrm{m}$. and 5 p.m. The mice were tested only once.

All experiments were carried out according to the National Institute of Health Guidelines for the care and use of laboratory animals, and the European Council Directive on 24 November 1986 for the Care and Use of Laboratory Animals (86/609/EEC), and were approved by the Local Ethics Committee.

Drugs. The following drugs were used: lithium chloride (Merc, Germany), 5-hydroxytryptophan (Sigma, USA), p-chlorphenylalanine (Sigma, USA), carbidopa (Sigma, USA), 5,7-dihydroxytryptamine (Sigma, USA), reserpine (Ciba, Switzerland), ritanserine (RBI, USA). In this experiment, for administration, 5-hydroxytryptophan, carbidopa and p-chlorphenylalanine were suspended in Tween 80 (Sigma, USA), while lithium chloride, reserpine and ritanserine were dissolved in distilled water. Moreover, 5,7-dihydroxytryptamine was dissolved in physiological saline containing $0,1 \%$ ascorbinic acid (Pliva, Poland). The drugs were injected intraperitoneally (i.p.) in a volume of $10 \mathrm{ml} / \mathrm{kg}$, subcutaneously (s.c.) $-5 \mathrm{ml} / \mathrm{kg}$ of body weight, and intracerebroventricularly (i.v.c.) - in a volume of $5 \mu 1$. The mice assigned to control received an injection of the appropriate vehicle. The drug solutions were prepared just prior to starting the experiments.

The head-twitch response. The head twitch response is defined as a spontaneous rotation of the head, neck and shoulders of the mice. Such response was counted for a 60 minute period - 6 times for 1 minute at 10 minute intervals following injection of this drug. The doses of 5-HTP in this study were: at $50 \mathrm{mg} / \mathrm{kg}$ with carbidopa (at $10 \mathrm{mg} / \mathrm{kg}$ ) or 5 -HTP alone $-150 \mathrm{mg} / \mathrm{kg}$. Lithium chloride $(\mathrm{LiCl})$ was given in doses of 100 or $200 \mathrm{mg} / \mathrm{kg}$ i.p., 30 minutes before administration of the 5-HTP, or 5-HTP and carbidopa.

Depletion of serotonin in the brain. For the study of endogenous serotonin depletion, the mice were pretreated with reserpine (blockage of amine storage) or p-chlorphenylalanine (pCPA) once daily for 3 days.

Lesioning of brain serotonergic neuron. The selective destruction of serotonin containing nerve terminals in the brain was induced by administration of 5.7-dihydroxytryptamine (5.7-DHT - 25, 50, $75 \mu \mathrm{g})$ injected intraventricularly (i.v.c.) with a Hamilton syringe, at a volume of $5 \mu \mathrm{l}$ - as described by Herman. For control purposes, control animals were injected with the $5 \mu$ l saline ascorbate vehicle $(0,1 \%)$ alone. The mice used in this study were allowed 8 days to recover from the lesioning procedure. After that time, $\mathrm{LiCl}$ was given at doses of 100 and $200 \mathrm{mg} / \mathrm{kg}$, and 30 minutes later, 5-HTP was administered in a dose of $150 \mathrm{mg} / \mathrm{kg}$ alone or $50 \mathrm{mg} / \mathrm{kg}$ with carbidopa at $10 \mathrm{mg} / \mathrm{kg}$.

Statistical analysis. All results were statistically analyzed using Student's t- test. Differences with $\mathrm{p}<0.05$ were considered statistically significant.

\section{RESULTS}

\section{The head twitch response induced by lithium in combination with 5-hydroxytryptophan and with 5-hydroxytryptophan and carbidopa}

Lithium chloride given at doses of 100 and $200 \mathrm{mg} / \mathrm{kg}$ in combination with either 5 -HTP $(150 \mathrm{mg} / \mathrm{kg})$ alone or with 5 -HTP $(50 \mathrm{mg} / \mathrm{kg})$ and carbidopa $(10 \mathrm{mg} / \mathrm{kg})$, significantly enhanced head-twitch response in mice $(\mathrm{p}<0.02, \mathrm{p}<0.001$ vs 5 -HTP, and $\mathrm{p}<0.01, \mathrm{p}<0.001$ vs 5 -HTP, carbidopa) (Fig.1).

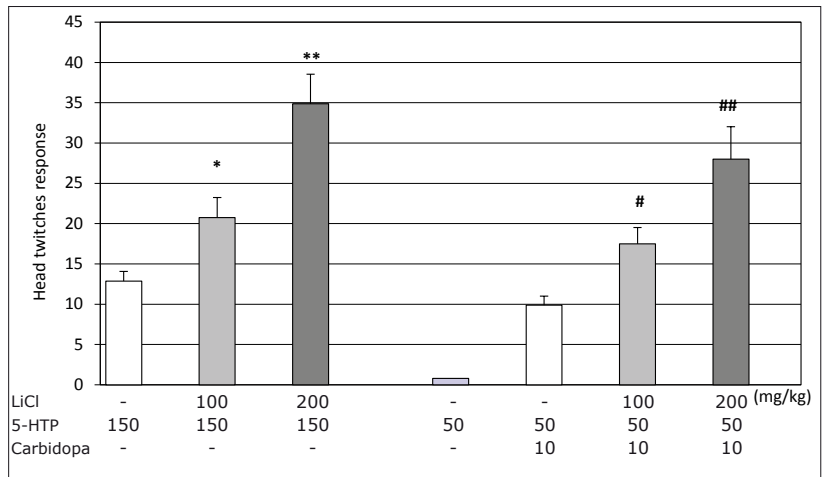

${ }^{*} \mathrm{p}<0.02,{ }^{* *} \mathrm{p}<0.001$ vs 5 -HTP, \#p $<0.01, \# \# \mathrm{p}<0.001$ vs 5 -HTP+carbidopa

Mice were injected with lithium chloride ( $\mathrm{LiCl}$ ) at doses of 100 and 200 $\mathrm{mg} / \mathrm{kg}$, and 30 minutes later 5-hydroxytryptophan (5-HTP) in the dose causing head twitches $-150 \mathrm{mg} / \mathrm{kg}$.

$\mathrm{LiCl}$ was administered at doses of 100 and $200 \mathrm{mg} / \mathrm{kg}$, and after 30 minutes, mice were given carbidopa $(10 \mathrm{mg} / \mathrm{kg})$, and after another 30 minutes - 5-HTP at the threshold dose of $50 \mathrm{mg} / \mathrm{kg}$. All injection were made i.p.

Figure 1. Effects of lithium chloride on the head twitches produced by 5 -hydroxytryptophan and carbidopa with 5-hydroxytryptophan in mice

\section{Effects of serotonin receptor blocking agent}

The head twitch response induced by lithium (100 and $200 \mathrm{mg} / \mathrm{kg})$ in combination with 5 -HTP $(150 \mathrm{mg} / \mathrm{kg})$ was significantly reduced by the administration of the 5-HT2 selective antagonist - ritanserine - given at both doses of 0.05 and $0.1 \mathrm{mg} / \mathrm{kg}(\mathrm{p}<0.05, \mathrm{p}<.0 .01, \mathrm{p}<0.001$ vs 5 -HTP and $\mathrm{p}<0.05, \mathrm{p}<0.01 \mathrm{vs} \mathrm{LiCl}+5-\mathrm{HTP}$ ) (Fig.2). 


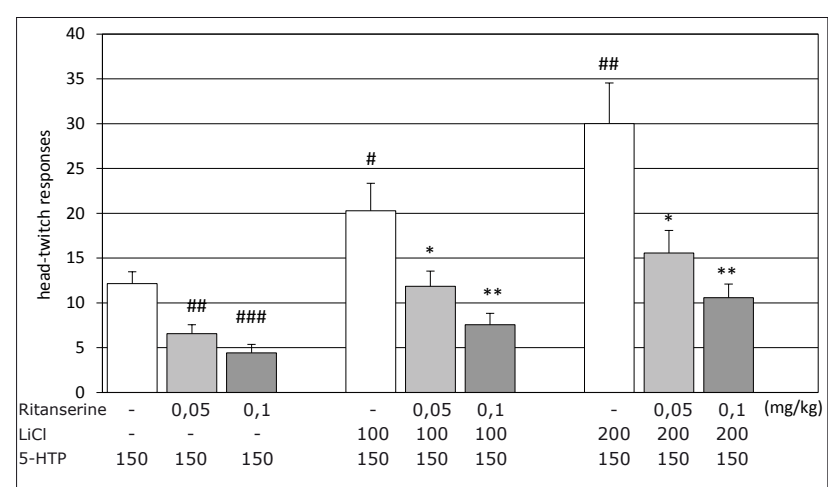

$\# p<0.05, \# \# p<.0 .01, \# \#$ p $<0.001$ vs $5-H T P, * p<0.05, * * p<0.01$ vs LiCl+5-HTP

Mice were injected with ritanserine at the doses of 0.05 and $0.1 \mathrm{mg} / \mathrm{kg}$ i.p. After 30 minutes $\mathrm{LiCl}$ was administered at the doses of 100 and 200 $\mathrm{mg} / \mathrm{kg}$, and after another 30 minutes $-5-\mathrm{HTP}$ at the dose causing head twitches $(150 \mathrm{mg} / \mathrm{kg})$ i.p.

Figure 2. Effects of ritanserine on the enhanced lithium chloride head twitches produced by 5-hydroxytryptophan in mice

\section{Effects of pretreatment with 5,7-dihydroxytryptamine}

The intraventricularly injection of 5.7-DHT (50 and $75 \mu \mathrm{g}$ / mouse) 8 days before the test, significantly decreased the head-twitch response induced by 5 -HTP $(150 \mathrm{mg} / \mathrm{kg})$ alone or by the combination of lithium $(200 \mathrm{mg} / \mathrm{kg})$ and $5-\mathrm{HTP}$ $(150 \mathrm{mg} / \mathrm{kg})(\mathrm{p}<0.05, \mathrm{p}<0.01, \mathrm{p}<0.001 \mathrm{vs} 5-\mathrm{HTP}$ and $\mathrm{p}<0.001$ vs $\mathrm{LiCl}+5$-HTP). However, 5.7-DHT given i.v.c. at the dose of $25 \mu \mathrm{g} /$ mouse 8 days before the test did not alter the 5-HTP and lithium - 5-HTP induced head-twitch response (Fig.3).

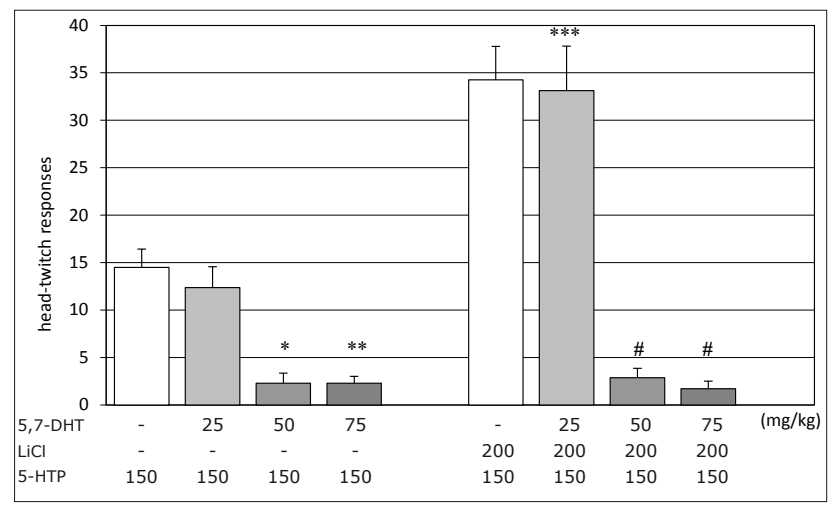

${ }^{*} \mathrm{p}<0.05,{ }^{* *} \mathrm{p}<0.01,{ }^{* * *} \mathrm{p}<0.001$ vs 5-HTP, \#p $<0.001$ vs LiCl+5-HTP

5.7-dihydroxytryptamine $(25,50,75$ ug) was given eight times, every 24 hours, i.v.c.

On the eighth day mice were injected with $\mathrm{LiCl}(100$ and $200 \mathrm{mg} / \mathrm{kg}$ ) and after 30 minutes - 5-HTP (150 mg/kg) i.p.

Figure 3. Effects of 5.7-dihydroxytryptamine on head twitches produced by 5 -hydroxytryptophan and lithium chloride in mice

\section{Influences of drug affecting serotonin synthesis and storage of serotonin in nerve terminals}

PCPA pretreatment of mice at the dose of $250 \mathrm{mg} / \mathrm{kg}$ given 3 times every $24 \mathrm{~h}$, significantly inhibited the headtwitch response induced by 5-hydroxytryptophan $(150 \mathrm{mg} /$ $\mathrm{kg}$ ) administration alone or by administration of lithium (100 and $200 \mathrm{mg} / \mathrm{kg})$ with 5 -HTP $(150 \mathrm{mg} / \mathrm{kg})$ or by administration of the combination of lithium $(100$ and $200 \mathrm{mg} /$ $\mathrm{kg}), 5$-HTP $(50 \mathrm{mg} / \mathrm{kg})$ and carbidopa $(10 \mathrm{mg} / \mathrm{kg})(\mathrm{p}<0.02$, $\mathrm{p}<0.001$ vs 5 -HTP or 5 -HTP+carbidopa and $\mathrm{p}<0.05$, $\mathrm{p}<0.01 \mathrm{vs} \mathrm{LiCl}+5-\mathrm{HTP}$ or $\mathrm{LiCl}+5-\mathrm{HTP}+$ carbidopa) (Fig.4).

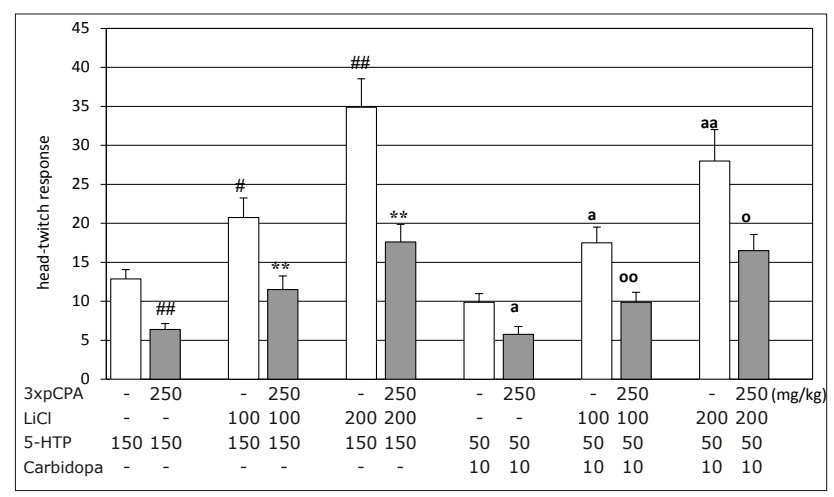

$\# p<0.02, \#$ p $<0.001$ vs $5-H T P,{ }^{*} p<0.05,{ }^{* *} p<0.01$ vs LiCl $+5-H T P$, a $p<0.02$, a a $p<0.001$ vs 5-HTP+carbidopa, ㅇ $p<0.05$, oo $p<0.01$ vs LiCl+5-HTP+carbidopa

Mice were injected with $p$-chlorphenylalanine (pCPA) at the dose of 250 $\mathrm{mg} / \mathrm{kg}$, three times every 24 hours i.p. 72 hours after the last dose of p-CPA, $\mathrm{LiCl}$ was given at doses of 100 and $200 \mathrm{mg} / \mathrm{kg}$. 30 minutes after the administration of $\mathrm{LiCl}$ were injected: 5 -HTP $(150 \mathrm{mg} / \mathrm{kg})$ or carbidopa (10 mg/kg) and after the next 30 minutes - 5-HTP (50 mg/kg), causing head twitches.

Figure 4. Effects of p-chlorphenylalanine on the enhanced by lithium chloride head twitches produced by 5 -hydroxytryptophan or 5-hydroxytryptophan and carbidopa in mice

Reserpine (2.5 mg/kg 20h prior to the test) and pCPA ( $250 \mathrm{mg} / \mathrm{kg} 2 \mathrm{~h}$ prior to the test) given alone did not change the head-twitch response induced by 5 -HTP $(150 \mathrm{mg} / \mathrm{kg})$ or by the combination of lithium $(100 \mathrm{mg} / \mathrm{kg})$ and $5-\mathrm{HTP}$ $(150 \mathrm{mg} / \mathrm{kg})$. However, lithium given in a dose of $200 \mathrm{mg} /$ $\mathrm{kg}$ with 5-HTP $(150 \mathrm{mg} / \mathrm{kg})$ significantly enhanced headtwitch response in reserpinised mice. When the mice were pretreated with reserpine $(2.5 \mathrm{mg} / \mathrm{kg})$ and pCPA $(250 \mathrm{mg} /$ $\mathrm{kg})$, the head-twitch response produced by 5 -HTP $(150 \mathrm{mg} /$ $\mathrm{kg}$ ) or by a combination of lithium (100 and $200 \mathrm{mg} / \mathrm{kg}$ ) with 5 -HTP $(150 \mathrm{mg} / \mathrm{kg})$ was significantly inhibited $(\mathrm{p}<0.01$ vs 5 -HTP and $\mathrm{p}<0.05$ vs $\mathrm{LiCl}+5-\mathrm{HTP}$ and $\mathrm{p}<0.01$ vs reserpine+5-HTP) (Fig.5).

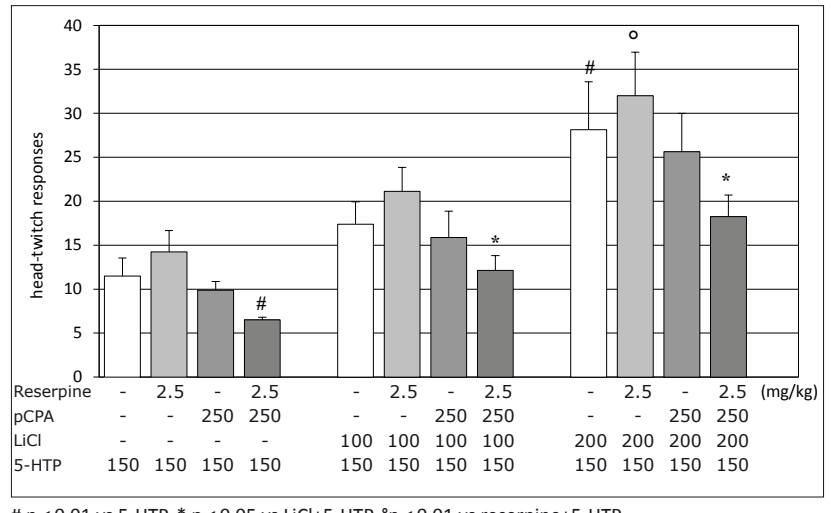

$\# p<0.01$ vs $5-$ HTP, ${ }^{*} p<0.05$ vs LiCl+5-HTP, ${ }^{\circ} p<0.01$ vs reserpine+5-HTP

Mice were injected with reserpine at the dose of $2.5 \mathrm{mg} / \mathrm{kg}$, only once, subcutaneously (s.c.).

After 20 hours pCPA was administered at the dose of $250 \mathrm{mg} / \mathrm{kg}$ i.p. Two hours later $\mathrm{LiCl}$ was administered at the doses of 100 and $200 \mathrm{mg} / \mathrm{kg}$, and after 30 minutes - 5-HTP at the dose of $150 \mathrm{mg} / \mathrm{kg}$ i.p.

Figure 5. Effects of p-chlorphenylalanine in combination with reserpine on the enhanced lithium chloride head twitches produced by 5-hydroxytryptophan in mice 


\section{DISCUSSION}

Numerous reports in the literature indicate that lithium has an affect upon the neurons of the cholinergic, adrenergic and serotonin systems in the CNS. Indeed, biochemical studies have shown that lithium enhances the release of serotonin, norepinephrine and acetylcholine from nerve endings. This is confirmed by the researches of many authors, who showed the stimulating effect of lithium on serotonergic transduction $[1,3]$. However, studies carried out so far do not provide a single image of the changes induced by lithium administration in these neurotransmitter systems.

In behavioral studies, in order to assess the impact of drugs on serotonergic transduction, the experimental model of head twitch response is employed. Head twitching is provoked by the direct precursor of serotonin (5-hydroxytryptophan, 5-HTP), and by selective ([(+/-)-1-(2.5-dimetoxy-4-iodophenyl)-2-aminopropane], DOI) and non-selective ( $\alpha$-methyl-5-hydroxytryptamine) agonists of the serotonin receptors 5-HT2A and the receptor agonists 5-HT1A (8-OH-DPAT, buspirone). It is also thought to be brought about by lithium chloride administration in rats and mice $[4,9,18]$. The results of these studies suggest that lithium may increase the transduction in neurons of the serotonergic system by increasing the release of serotonin from the nerve endings.

Our study showed that the lithium chloride, when administered alone at different doses, does not cause head twitching in these animals. However, lithium, depending on the dose, increased the number of head twitches brought about by $5-\mathrm{HTP}(150 \mathrm{mg} / \mathrm{kg})$ administered at a dose causing head twitching, and did not cause head twitching in mice given 5 -HTP $(50 \mathrm{mg} / \mathrm{kg})$ in a dose not provoking head twitching in these animals. These results indicate that the effect of lithium may depend on the concentration of serotonin synthesized in the nerve endings from 5-HTP and released into the synaptic cleft.

Swann et al. [16], Berggren [2] and Herrero et al. [8] have shown that lithium increases the transport of tryptophan into the brain, thereby increasing its concentration in the serotoninergic endings and inducing the synthesis of serotonin released into the synaptic cleft.

In order to increase the concentration of serotonin in the brain and in the serotoninergic endings, experiments were performed in which animals were treated with 5-HTP with the peripheral decarboxylase inhibitor - carbidopa, which increases the concentration of 5-HTP in the brain and the synthesis of serotonin in the serotoninergic endings [7]. The results of research conducted in this study showed that lithium induced head twitching in mice which were given 5-HTP at a dose not causing head twitching when administered along with carbidopa. These results indicate that the head twitches induced by lithium and 5-HTP administered at a dose not causing head twitching, but with co-administration of carbidopa, may be provoked by the intensity induced by the lithium of 5-HTP transport into the brain, the increase of the level of serotonin in the nerve endings and the increase of serotonin release into the synaptic cleft. This has been confirmed by the results of Treiser et al. [17] and Blier and Montigny [3], who showed that lithium increases the transport of 5-HTP in the brain and increases the release of serotonin from serotonergic terminals.

In order to assess the effect of lithium on serotonergic nerve endings, serotonergic compounds reducing serotonergic transduction (reserpine, p-chlorophenylalanine 5.7-dihydroxytryptamine and ritanserin) were administered. Reserpine reduces serotonergic transduction by bringing about a significant reduction in the level of serotonin in the brain [11]. It also inhibits the storage of serotonin in the deep synaptic vesicles without affecting serotonin levels in the shallow synaptic vesicles from which newly synthesized serotonin is released. In order to increase the level of newly synthesized serotonin in the nerve endings, in our work, mice were treated with a reserpine precursor of serotonin - 5-HTP, applied in two doses. The result of this work demonstrated that lithium given at different doses, with 5-HTP applied in doses not causing head twitching, did not induce head twitching in non-reserpinised mice, whereas it did in mice which were reserpinised. These results are consistent with that obtained by Yamada and Furukawa [18], who revealed that lithium increases the number of episodes of head twitching provoked by 5-HTP in reserpinised mice.

In attempting to answer the question as to whether lithium increases the release of serotonin from the nerve endings, we conducted experiments with compounds that inhibit the synthesis of serotonin in the nerve endings (- p-chlorphenylalanine) or induced neurodegeneration of the serotonergic terminals (- 5.7 - dihydroxytryptamine). In this work, we found that P-chlorphenylalanine administration significantly reduced the number of head twitches induced by the administration of lithium with 5-HTP. This effect indicates that lithium and 5-HTP provokes head twitching in mice, if the synthesis of serotonin in nerve terminals is maintained, however, 5.7-dihydroxytryptamine (5.7-DHT) administered intracerebrally selectively destroys $70-80 \%$ of the nerve endings of the serotonergic neurons. The results of the studies in mice have demonstrated that the destruction of the 5.7-DHT of serotonergic nerve terminals completely inhibits head twitching provoked by the combination of lithium administration with 5-HTP as used in the doses bringing about head twitches. These results suggest that lithium enhances serotonin release from nerve endings [5].

It was also shown that increased head twitch response, enhanced by lithium and induced by 5 -HTP, was blocked by the selective antagonist of the serotonin receptors 5-HT2ritanserin. Similar results were obtained by Matsumoto et al. [13] in the model of head twitching in mice.

In conclusion, the results obtained in this study indicate that lithium enhances serotonin transduction in the central nervous system, by increasing serotonin release from the nerve terminals into the synaptic cleft, where the serotonin synthesis is maintained.

\section{REFERENCES}

1. Bauer M. et al.: Lithium augmentation therapy in refractory depression: clinical evidence and neurobiological mechanisms. Can. J.Psychiatry, 48(7), 440, 2003.

2. Berggren U.: Effects of short-term lithium administration on tryptophan levels and 5-hydroxytryptamine synthesis in whole brain and brain regions in rats. J. Neural. Transm., 69, 115, 1987. 
3. Blier P., deMontigny C.: Short-term lithium administration enhances serotonergic neurotransmission: electrophysiological evidence in the rat CNS. Eur. J. Pharmacol., 113, 69, 1985.

4. Darmani N.A.: Cannabinoids of diverse structure inhibit two DOIinduced 5-HT(2A) receptor-mediated behaviors in mice. Pharmacol. Bioch. Beh., 68(2), 311, 2001.

5. Fletcher P.J., Korth K.M., Chambers J.W.: Selective destruction of brain serotonin neurons by 5,7-dihydroxytryptamine increases responding for a conditioned reward. Psychopharmacol., 147, 291, 1999.

6. Granoff M.I., Ashby C.R.: The effect of the repeated administration of the compound 3,4-metylenedioxymethamphetamine on the response of rats to the 5-HT2A,C receptor agonist (+/-)-1-(2,5-dimethoxy-4iodophenyl)-2-aminopropane (DOI). Neuropsychobiol., 37, 36, 1998.

7. Heal D.J. et al.: The influence of central noradrenergic function on 5-HT2-mediated head-twitch response in mice: possible implications for the actions of antidepressant drugs. Psychopharmacol., 89, 414 1986.

8. Herrero E. et al.: Tryptophan transport into plasma membrane vesicles derived from rat brain synpatosomes. J. Neurochem., 40, 332, 1983.

9. Hotta I., Yamawaki S.: Possible involvement of presynaptic 5-HT autoreceptors in effect of lithium on 5-HT release in hippocampus of rat. Neuropsychopharmacol., 27, 987, 1988.
10. Kofman O., Patishi Y.: Interactions of lithium and drugs that effect signal transduction on behaviour in rats. Eur. Neuropsychopharmacol., 9, 385, 1999.

11. Kuhn D.M., Wolf W.A., Youdim M.B.H.: 5-Hydroxytryptamine release in vivo from a cytoplasmic pool: studies on the 5-HT behavioural syndrome in reserpinized rats. Br. J. Pharmacol., 84, 121, 1985.

12. Licht R.W.: Lithium: still a major option in the management of bipolar disorder. CNS Neuroscience Therpeutics, 18, 219, 2012.

13. Matsumoto K. et al.: $\alpha 2$-adrenoceptor antagonists reverse the 5-HT2 receptor antagonist suppresion of head-twitch behavior in mice. Pharmacol. Bioch. Behav., 56, 417, 1997.

14. McDonald L.M. et al.: Enhancement of latent inhibition by two 5-HT2A receptor antagonists only when given at both pre-exposure and conditioning. Psychopharmacol., 169(3-4), 321, 2003.

15. Munoz-Castaneda J.R. et al.: Role of serotonin in cerebral oxidative stress in rats. Acta Neurobiol. Exp., 66, 1, 2006.

16. Swann A.C. et al.: Differential effects of short and long term lithium on tryptophan uptake and serotonergic function in cat brain. Life Sci., 28, 247, 1986.

17. Treiser S.L. et al.: Lithium increases serotonin release and decreases serotonin receptors in the hippocampus. Science, 213, 1529, 1981.

18. Yamada K., Furukawa T.: Serotonergic function in mouse head twitches by lithium and reserpine. Psychopharmacol., 28, 61(3), $255,1979$. 